\title{
Efficiency and Economical Assessment of a Solar Powered Dryer Combined with a Biomass Gasification System
}

\author{
Marco Puglia*, Andrea Rizzo, Nicolò Morselli, Paolo Tartarini \\ Department of Engineering “Enzo Ferrari”, University of Modena and Reggio Emilia, Via Vivarelli 10/1 41125 Modena, Italy
}

Corresponding author email: marco.puglia@unimore.it

https://doi.org/10.18280/ijht.370306

Received: 16 May 2019

Accepted: 20 August 2019

\section{Keywords:}

biomass, efficiency, gasification, thermal solar power

\begin{abstract}
This work follows the study presented in Matera at the 4th AIGE/IIETA International Conference titled: "Analysis of energy saving potential of combined thermal solar power and micro scale gasification systems". This previous work was focused on the advantages gained through the integration between thermal solar power and a small scale gasification system and how to maximize them. The results showed that the best way to combine the two systems is to use to heat generated with the thermal solar power to dry the fuel rather than heat up the gasification air. In this second work the best scenario will be analyzed considering the annual irradiance in the Province of Modena in northern Italy. The systems considered in this study were the APL PP30, a biomass gasifier genset system able to produce $22 \mathrm{kWel}$ at $50 \mathrm{~Hz}$, and the Chromasun Micro-Concentrator (MCT), a high performance solar collector able of $2.2 \mathrm{kWt}$ output peak at DNI of $1000 \mathrm{~W} \mathrm{~m}^{-2}$. Results showed that four thermal solar units are sufficient to dry the biomass consumed in a year by the gasifier, increasing substantially its efficiency. The economic feasibility of this scenario was investigated considering a possible substitution of the methane as the heat source of the biomass dryer.

Considering a discount rate of $5 \%$ and an inflation rate of $2.5 \%$ it is possible to have a positive NPV after 22 years from the purchase of the 4 thermal solar units. Furthermore, it is possible to save $2286 \mathrm{~kg}$ of $\mathrm{CO}_{2}$ using solar energy rather than methane every year.
\end{abstract}

\section{INTRODUCTION}

This work follows the study presented in Matera at the 4th AIGE/IIETA International Conference [1].

Fossil fuels find an interesting alternative for power production in renewable sources [2]. Nevertheless the energy produced through solar and wind is subjected to great volatility, therefore it should be coupled with a stable and programmable energy source [3] like biomass [4]. In particular biomass gasification can be a very interesting technology for a sustainable development $[5,6]$. Through this thermochemical process, the biomass is converted into a gaseous flammable gas, called syngas [4] that can fuel internal combustion engines [7, 8]. Vine prunings [9], poplar wood chips [10, 11], woody residues deriving from river banks maintenance [12], corn cobs [13] and corn stover [14, 15] are just a few examples of agro-forestry by product that can efficiently converted through gasification process. The moisture of the biomass plays an important role in gasification, in particular using dry biomass instead of wet it is possible to significantly increase the efficiency of the process [16].

In this paper, a possible integration of a thermal solar power and gasification will be presented and evaluated.

The considered gasifier unit was the APL PP30, a biomass gasifier genset able to produce $22 \mathrm{kWel}$ and $44 \mathrm{kWth}$ at $50 \mathrm{~Hz}$ with a specific consumption of $1 \mathrm{~kg}$ of dry wood for every $\mathrm{kWel}$ produced [17]. The considered thermal solar unit was the Chromasun Micro-Concentrator (MCT), it is a high performance solar collector able of $2.2 \mathrm{kWth}$ output peak at DNI of $1000 \mathrm{~W} / \mathrm{m}^{2}$ [18]. An annual amount of gasifier operating hours was considered and knowing the biomass consumption it was possible to calculate the heat necessary to dry the biomass. Consequently, the number of thermal solar units was evaluated calculating the annual irradiance in the Province of Modena in northern Italy. Once the scenario was established, it was economic evaluated through the net present value method of investment appraisal considering a certain discount and inflation rate.

\section{MATERIALS AND METHODS}

\subsection{Gasifier model}

The gasifier used in the simulation in this work is a $22 \mathrm{~kW}_{\mathrm{cl}}$ (a) $50 \mathrm{~Hz}$ gasifier-engine pilot plant. The model chosen is the PP30 Power Pallet (Figure 1), manufactured by the company ALL Power Labs [17]. The system is composed of a fuel hopper of about $0.33 \mathrm{~m}^{3}$ of volume, an auger biomass moving system from the hopper to the reactor, a single throat downdraft fixed bed gasifier provided with a filtration stage and an IC engine linked to a gen-head for electrical power production. Table 1 resumes the main features of the Power Pallet (depicted in Figure 1) [17].

Table 1. Main Technical specifications of the PP30 [17]

\begin{tabular}{cc}
\hline Gasifier & Imbert Downdraft \\
Biomass & Woodchips G30 \\
Biomass flow (dry base) & $22 \mathrm{~kg} \mathrm{~h}^{-1}$ \\
IC Engine & Ashok Leiland 4.0 1 \\
Electrical Generator & Marathon 284CSL1542, 12 wire \\
\hline
\end{tabular}




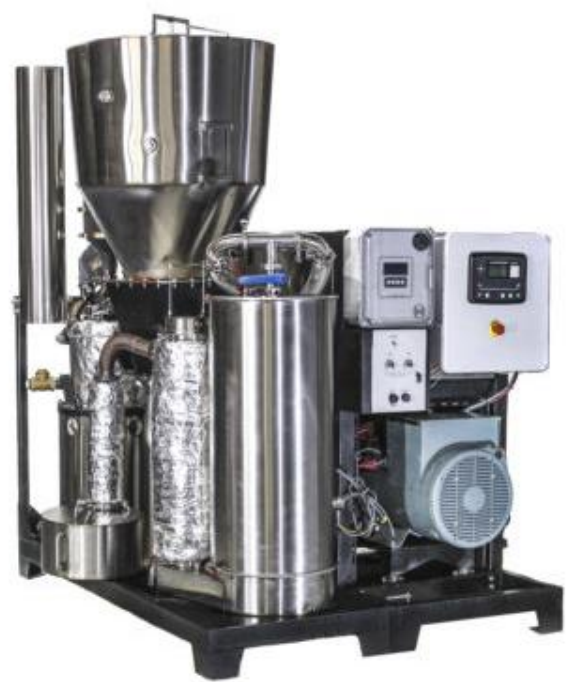

Figure 1. PP30 power pallet gasifier [17]

The biomass fuel used in the simulation is fir wood chips; the Higher Heating Value (HHV) is evaluated by the formula suggested by Channiwala [19]:

$$
\begin{aligned}
& H H V_{d b}=349.1 C_{d b}+1178.3 H_{d b}+100.5 S_{d b}+ \\
& 103.4 O_{d b}+15.1 N_{d b}+21.1 A S H_{d b}
\end{aligned}
$$

where, $\mathrm{C}, \mathrm{H}, \mathrm{N}, \mathrm{S}, \mathrm{O}$ [\%wt.] are the weight fractions of the respective elements, $\mathrm{ASH}$ [\%wt.] is the ash content in the dry sample. Table 2 resumes the elemental composition of the biomass taken from Ref. [20].

Table 2. Elemental composition of biomass [20]

\begin{tabular}{cc}
\hline Input & Value (\% dry-basis) \\
\hline ASH & 0.3 \\
C & 50.4 \\
H & 6.1 \\
N & 0.1 \\
S & 0.01 \\
O & 43.1 \\
\hline
\end{tabular}

In Table 3 the pre-fixed features of the Gasifier are listed. Moisture Content is assumed to be $35 \%$ for an as received humid biomass.

\begin{tabular}{|c|c|}
\hline Input & Value \\
\hline Dry wood Temperature [ $\left.\mathrm{T}_{\mathrm{BIO}, \mathrm{in}}\right]$ & $25^{\circ} \mathrm{C}$ \\
\hline Moisture Content [M.C.] & $35 \%$ \\
\hline Humid Wood mass flow $\left[\dot{M}_{b i o}\right]$ & $33,84 \mathrm{~kg} \mathrm{~h}^{-1}$ \\
\hline Gas. Air Temperature & $400^{\circ} \mathrm{C}$ \\
\hline Atmospheric Temperature & $25^{\circ} \mathrm{C}$ \\
\hline Annual operating hours & $2200 \mathrm{~h}$ \\
\hline
\end{tabular}

Table 3. Gasifier simulation input data

\subsection{Dryer and heat exchanger model}

In order to improve the overall efficiency of the gasifier, a complementary system consisting of the following component was modeled:

- Solar thermal heating modules "MCT" by Chromasun [18]

- Rotary dryer vehiculating biomass directly into the hopper

- Cross-flow Heat exchanger

The plant layout is depicted in Figure 2.

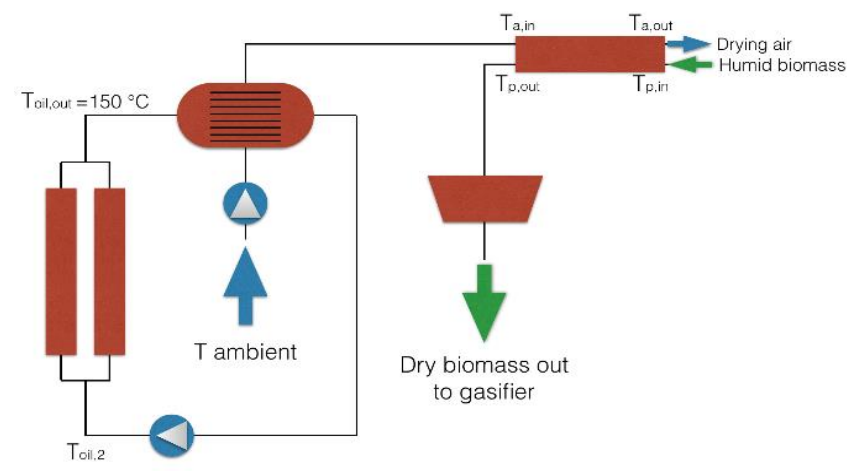

Figure 2. Complementary system layout [1]

The mean fluid circulating in the 'solar' circuit is a diathermic oil "THERMINOL 66" having a specific heat of $1.86 \mathrm{~kJ} \mathrm{~kg}^{-1}{ }^{\circ} \mathrm{C}^{-1}$ [21]. A blower pumps air inside the crossflow heat exchanger, this air will be conveyed to the dryer in a counter-flow configuration with the wood chips.

The main calculations to be carried out are for the dryer; $T_{a, I N}$ and $T_{a, \text { OUT }}$ indicate respectively the temperature of the drying air flowing in the device when entering and when exiting. These values are fixed: $T_{a, I N}=105{ }^{\circ} \mathrm{C}$ and $T_{a, O U T}=30$ ${ }^{\circ} \mathrm{C}$. The power $\dot{Q}$ (multiplied by an efficiency coefficient of $0,97)$ is entirely used to dry the biomass:

$$
\dot{Q}=\dot{M}_{a} c_{p, a}\left(T_{a, I N}-T_{a, \text { OUT }}\right) 0.97
$$

where, $c_{p, a}\left[\mathrm{~kJ} \mathrm{~kg}^{-1}{ }^{\circ} \mathrm{C}^{-1}\right]$ is the specific heat capacity of the air and $\dot{M}_{a}$ the air flow necessary to dry the flow of biomass.

On another hand, the power absorbed to dry the biomass counter-flowing in the machine can be calculated with a simple formula [22]:

$$
\begin{array}{r}
\dot{Q}=\dot{M}_{b i o}\left(X_{\text {in }}-X_{\text {out }}\right) \Delta H_{\text {vap }}+ \\
\dot{M}_{b i o} c_{p, b i o}\left(T_{b i o, I N}-T_{b i o, \text { oUT }}\right)+\dot{Q}_{\text {loss }}
\end{array}
$$

The humidity ratio variation between $X_{\text {in }}=0.35$ and $X_{\text {out }}=0.20$ is the aim of this study, $\Delta H_{\text {vap }}=2349 \mathrm{~kJ} \mathrm{~kg}^{-1}{ }^{\circ} \mathrm{C}^{-1}$ [23] is the water evaporation heat.

The net biomass flow value $\dot{M}_{B I O}$ is driven by the feed consumption of the PP30 producing $22 \mathrm{~kW}$ and consuming 1 $\mathrm{kg} / \mathrm{h}$ each $\mathrm{kW}$ of dry base wood chips [17]; if the incoming biomass has a humidity content of $35 \%$ wet base, the total flow rate will be $\dot{M}_{B I O}=33,84 \mathrm{~kg} \mathrm{~h}^{-1}$.

The second term of the equation represents the power necessary to heat the biomass from a temperature of $T_{b i o, I N}=$ $25{ }^{\circ} \mathrm{C}$ to $T_{\text {bio,ouT }}=100{ }^{\circ} \mathrm{C}$, the heat capacity of the biomass used is $c_{p, b i o}=1,97 \mathrm{~kJ} \mathrm{~kg}^{-1}{ }^{\circ} \mathrm{C}^{-1}[24]$.

$\dot{Q}_{\text {loss }}$ stands for the power not recovered and theoretically available from the output air $T_{a, \text { OUT }}=30^{\circ} \mathrm{C}$.

$$
\begin{gathered}
\dot{Q}=\dot{M}_{a} c_{p, a}\left(T_{a, I N}-T_{a, \text { OUT }}\right)=\dot{M}_{b i o}\left(X_{\text {in }}-X_{\text {out }}\right) \Delta H_{v a p}+ \\
\dot{M}_{b i o} c_{p, b i o}\left(T_{b i o, I N}-T_{b i o, \text { OUT }}\right)+\dot{Q}_{\text {loss }}
\end{gathered}
$$

This heat power is supplied by a "solar generator" field consisting of 4 MCT panels as the one depicted in Figure 3.

The Therminol 66 flows in a captating pipe in each panel, heated up to $110{ }^{\circ} \mathrm{C}$ with solar radiation concentrated by 20 Fresnel reflection optics, and consequently yielding heat power to the atmospheric air inside the exchanger. 
In fact heating the biomass up to $100{ }^{\circ} \mathrm{C}$ is considered to be a conservative take.

Each device has a $3.5 \mathrm{~m}^{2}$ reflecting surface, operating with a mean efficiency coefficient of 0.59 [18] (this value is linked to the temperature of $110{ }^{\circ} \mathrm{C}$, efficiency decreases with an increase of the oil operating temperature).

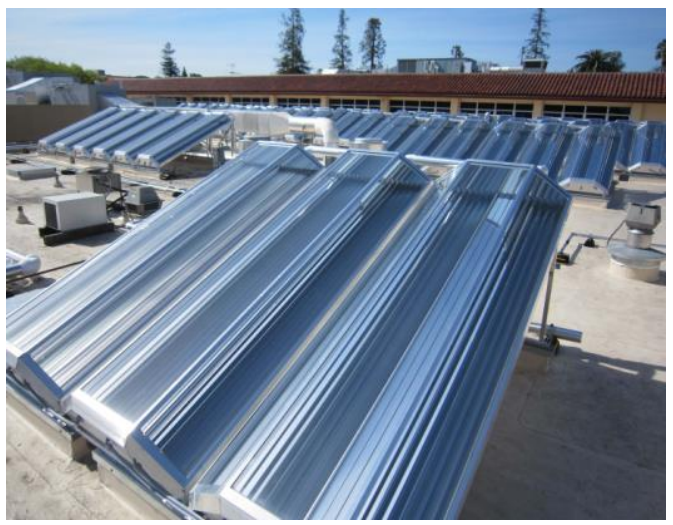

Figure 3. MCT solar panel [18]

During the calculations it is very important to keep the content of humidity of the drying air below saturation point throughout the process, to avoid having humidity re-condense on the biomass.

Specifically, the Absolute Humidity $X_{\text {OUT }}$ at the $T_{a, \text { OUT }}$ conditions needs to be below saturation.

To simulate the efficiency of an Imbert downdraft gasifier like in the PP30, a software developed by the Denmark Technical University (DTU) in 2000 was used [25].

The gasifier efficiency is ratio between the chemical energy going out with the syngas and the one entering in the gasifier with the biomass $[26,27]$.

Figure 4 depicts the main interface of the software, the INPUT data as previously discussed was entered in the small boxes, in this case the initial M.C. value of $35 \%$ was considered. The aim is to dry the biomass to a M.C. value of $20 \%$ and verify the increase in terms of overall efficiency.

It is important to point out that the temperature of the biomass entered is $25{ }^{\circ} \mathrm{C}$; this value is different from the $T_{\text {bio,IN }}=100{ }^{\circ} \mathrm{C}$ because it is assumed that the biomass is stocked after being dried, and not immediately used in the gasifier.

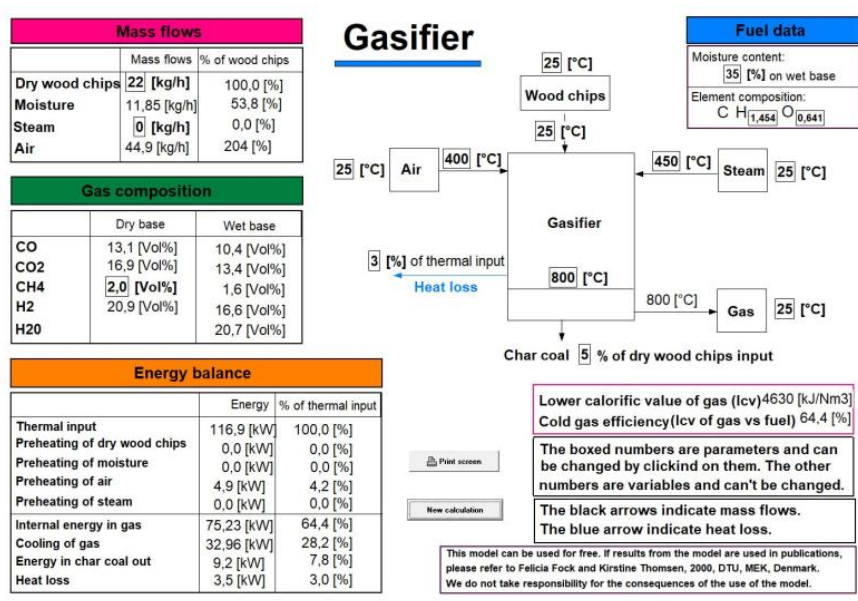

Figure 4. Screenshot of the software's main interface with $35 \%$ M.C. Input. [25]

\subsection{Economical assessment}

Based on the assumption that a dryer is necessary for a biomass gasification system, the economic feasibility was evaluated considering only the price of four Chromasun thermal solar units, and not the cost of the entire biomass dryer.

The panel price of $1000 € \mathrm{~m}^{-2}$ was directly provided by the manufacturer, therefore the $3.5 \mathrm{~m}^{2}$ for each unit lead to a total estimated cost of $14000 €$ for four panels. A discount rate of $5 \%$ and an inflation rate of $2.5 \%$ was considered [28]. The economic benefits of having the Chromasun panel derives from the avoided purchasing of natural gas to provide the heat necessary for drying. Natural gas price was set to $0.0721 €$ $\mathrm{kWh}^{-1}$ in accordance with the Eurostat second semester 2018 Gas prices for non-household consumers [29] for a consumption lower than 1000 GJ and with all the taxes included. The investment appraisal method used was the net present value. If the NPV is positive it means that the project should be accepted [30]. It is calculated as the sum of the annul cash flows divided by $(1+r)^{n}$, where $r$ is the discount rate and $\mathrm{n}$ is the number of years.

\section{RESULTS AND DISCUSSION}

The power $\dot{Q}$ needed by the dryer device to treat a biomass flow $\dot{M}_{B I O}=33,84 \mathrm{~kg} \mathrm{~h}^{-1}$ is $4.70 \mathrm{~kW}$, the needed mass air flow calculated is $\dot{M}_{a}=240 \mathrm{~kg} \mathrm{~h}^{-1}$.

The amount of heat power not used in the drying $\dot{Q}_{\text {loss }}$ is $0.33 \mathrm{~kW}$.

Losses can be reduced by decreasing the $T_{a, \text { OUT }}\left(\right.$ or $\dot{M}_{a}$ ), but this value is also connected to the humidity that can be contained in the drying air flow at a temperature of $30{ }^{\circ} \mathrm{C}$.

The Absolute Humidity of the air incoming at $T_{a, I N}=25^{\circ} \mathrm{C}$ matches the status of the atmospheric air at a relative humidity of $50 \%$.

The air exiting at a $T_{a, O U T}=30{ }^{\circ} \mathrm{C}$ also contains the humidity released by the biomass and, with these settings, reaches a relative humidity of $90 \%$.

The installment will be operating in Modena area, in Emilia Romagna (Italy); the data regarding solar radiation available in this particular location is available in the technical standard UNI 10349 - 1 [31, 32].

The study aims to evaluate the feasibility of the combined system in terms of consumption and production of energy year round.

The mean yearly radiation for a horizontal surface, as cited in the standard [32], is $1398 \mathrm{kWh} \mathrm{m}^{-2}$, therefore the energy produced by a single MCT panel is $2886 \mathrm{kWh}_{\text {year }}{ }^{-1}$.

A solar field of 4 MCT panels provides energy for an operation of the PP30 of $2223 \mathrm{~h}$ every year, therefore considering 2200 annual operating hours for a PP30, 4 solar units are sufficient to meet the dryer thermal needs.

Using the DTU software, it can be easily verified from Figure 5, that with a reduction of $15 \%$ of the M.C. of the biomass feed, the efficiency rises significantly (Cold Gas efficiency from $64.4 \%$ to $71.2 \%$ ).

It was calculated that the using the solar panel instead of natural gas there is a money saving of $832.61 €$ every year, (not considering inflation), this guarantees to have a positive net present value after 22 years, an amount of time in line with the solar installation [28]. Furthermore, the Chromasun solar units have a lifespan of 25 years as declared by the 
manufacturer.

A further point is that considering a lower heating value of $50.02 \mathrm{MJ} / \mathrm{kg}$ [33] and that for every $\mathrm{kg}$ of methane burned 2.75 $\mathrm{kg}$ of $\mathrm{CO}_{2}$ are produced, this scenario allows to avoid about $2286 \mathrm{~kg}$ of $\mathrm{CO}_{2}$ emission every year.

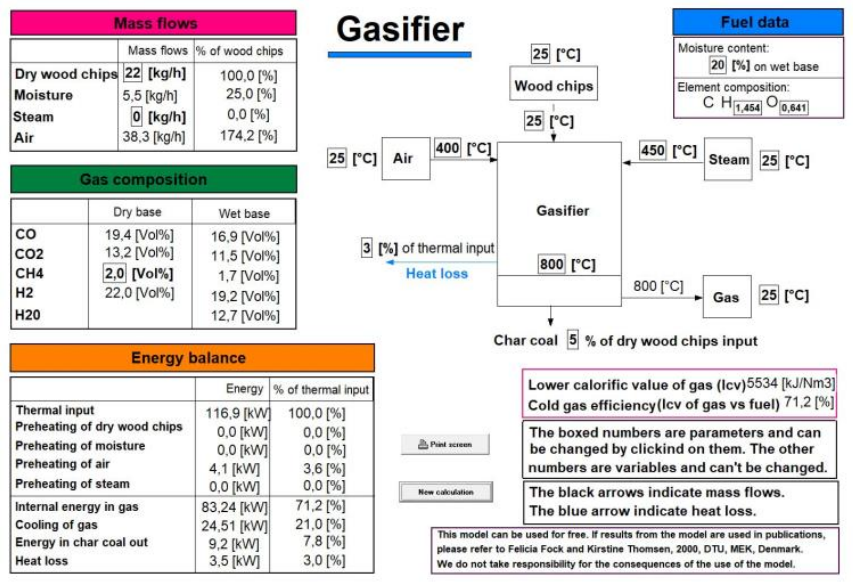

Figure 5. Screenshot of the software's main interface with $20 \%$ M.C. Input. [25]

\section{CONCLUSIONS}

The solution of combining Solar Thermal microconcentrator units to a Gasifier module has an interesting potential.

The increase in terms of efficiency of the reactor due the reduced M.C. in the biomass is one aspect that has been voluntarily put on the background, but has a huge relevance if studied in depth.

In this study, it has been emphasized the saving achieved avoiding the purchase of natural gas to run the dryer.

A device like the MCT, is a feasible solution in this range of small-scale installments, thanks to its high efficiency and high peak temperature of the mean fluid, compared to traditional Solar Thermal units.

The return of the investment is below the lifespan of the MCT modules, furthermore the NPV has been calculated without considering additional possible features:

- White Certificates provided as an incentive for a not polluting energy production methods.

- Fiscal deduction of part of the cost for investments for energy efficiency increase.

- Potentially higher production outcome of the panels if laid down with an inclined azimuth angle

In the future will be evaluated the possibility of substituting the thermal solar panel as the heat source for the dryer with a wood stove fueled with vine prunings, that can be an efficient [34] and low cost alternative.

\section{REFERENCES}

[1] Rizzo, A., Puglia, M., Morselli, N., Tartarini, P. (2019). Analysis of energy saving potential of combined thermal solar power and micro scale gasification systems. TIIJES, 63(2-4): 115-120. https://doi.org/10.18280/ti- ijes.632-401

[2] Rinaldini, C.A., Allesina, G., Pedrazzi, S., Mattarelli, E., Tartarini, P. (2019). Modeling and optimization of industrial internal combustion engines running on Diesel/syngas blends. Energy Conversion and Management, 182: 89-94. https://doi.org/10.1016/j.enconman.2018.12.070

[3] Liserre, M., Sauter, T., Hung, J., (2010). Future energy systems: integrating renewable energy sources into the smart power grid through industrial electronics. IEEE Industrial Electronics Magazine, 4(1): 18-37. https://doi.org/10.1109/MIE.2010.935861

[4] IEA. (2019). IEA Bioenergy Annual Report 2018. April 2019. Available: https://www.ieabioenergy.com/publications/ieabioenergy-annual-report-2018/.

[5] Quinlan, B., Kaufmann, B., Allesina, G., Pedrazzi, S., Hasty, J., Puglia, M., Morselli, N., Tartarini, P. (2017). The use of on-line colorimetry for tar content evaluation in gasification systems. International Journal of Heat and Technology, 35(Sp1): S145-S151. https://doi.org/10.18280/ijht.35Sp0120

[6] Allesina, G., Pedrazzi, S., Allegretti, F., Morselli, N., Puglia, M., Santunione, G., Tartarini, P. (2018). Gasification of cotton crop residues for combined power and biochar production in Mozambique. Applied Thermal Engineering, 139: 387-394. https://doi.org/10.1016/j.applthermaleng.2018.04.115

[7] Malaguti, V., Lodi, C., Sassatelli, M., Pedrazzi, S., Allesina, G., Tartarini, P. (2017). Dynamic behavior investigation of a micro biomass CHP system for residential use. International Journal of Heat and Technology, 35(S1): 172-178. https://doi.org/10.18280/ijht.35Sp0124

[8] Rinaldini, C.A., Allesina, G., Pedrazzi, S., Mattarelli, E., Savioli, T., Morselli, N., Puglia, M., Tartarini, P. (2017). Experimental investigation on a common rail diesel engine partially fuelled by syngas. Energy Conversion and Management, 138: 526-537. https://doi.org/10.1016/j.enconman.2017.02.034

[9] Allesina, G., Pedrazzi, S., Puglia, M., Morselli, N., Allegretti, F., Tartarini, P. (2018). Gasification and wine industry: Report on the use vine pruning as fuel in small -scale gasifiers. European Biomass Conference and Exhibition Proceedings, 26 $6^{\text {th }}$ EUBCE, pp. 722-725. https://doi.org/10.5071/26thEUBCE2018-2CV.2.19

[10] Allesina, G., Pedrazzi, S., Tartarini, P. (2013). Modeling and investigation of the channeling phenomenon in downdraft stratified gasifers. Bioresource Technology, 146: 704-712. https://doi.org/10.1016/j.biortech.2013.07.132

[11] Pedrazzi, S., Allesina, G., Tartarini, P. (2012). Aige conference: A kinetic model for a stratified downdraft gasifier. International Journal of Heat and Technology, 30(1): 41-44. https://doi.org/10.18280/ijht.300106

[12] Pedrazzi, S., Allesina, G., Morselli, N., Puglia, M., Barbieri, L., Lancellotti, I., Ceotto, E., Cappelli, G.A., Ginaldi, F., Giorgini, L., Malcevschi, A., Pederzini, C., Tartarini, P. (2017). The energetic recover of biomass from river maintenance: The REBAF project. In European Biomass Conference and Exhibition Proceedings, 25 $5^{\text {th }}$ EUBCE, pp. 52-57. https://doi.org/10.5071/25thEUBCE2017-1AO.7.3

[13] Allesina, G., Pedrazzi, S., Sgarbi, F., Pompeo, E., Roberti, 
C., Cristiano, V., Tartarini, P. (2015). Approaching sustainable development through energy management, the case of Fongo Tongo, Cameroon. International Journal of Energy and Environmental Engineering, 6(2): 121-127. https://doi.org/10.1007/s40095-014-0156-7

[14] Allesina, G., Pedrazzi, S., Montermini, L., Giorgini, L., Bortolani, G., Tartarini, P. (2014). Porous filtering media comparison through wet and dry sampling of fixed bed gasification products. Journal of Physics: Conference Series, 547(1): 012003. https://doi.org/10.1088/17426596/547/1/012003

[15] Allesina, G., Pedrazzi, S., Guidetti, L., Tartarini, P. (2015). Modeling of coupling gasification and anaerobic digestion processes for maize bioenergy conversion. Biomass and Bioenergy, 81: 444-451. https://doi.org/10.1016/j.biombioe.2015.07.010

[16] Wu, K.T., Chein, R.Y. (2015). Modeling of biomass gasification with preheated air at high temperatures. Energy Procedia, 75: 214-19. https://doi.org/10.1016/j.egypro.2015.07.307

[17] All Power Labs Inc. PP30 datasheet. July 2019.Available: http://www.allpowerlabs.com/wpcontent/uploads/2019/06/PP30OneSheet6_27_19Small. pdf

[18] Chromasun Inc. Chromasun MCT solar panel datasheet. April $2019 . \quad$ Available: http://chromasun.com/images/content/resources/MCT_ Thermal_Product_Spec_201106.pdf

[19] Channiwala S., Parikh P. (2002). A unified correlation for estimating HHV of solid. liquid and gaseous fuels. Fuel, 81(8): 1051-1063. https://doi.org/10.1016/S00162361(01)00131-4

[20] Galeno, G. (2007). Modellizzazione di un micro cogeneratore basato sulla tecnologia MCFC accoppiata ad un gassificatore di Biomassa. Ph.D. dissertation, Dept. Industrial Eng., Univ. ff Cassino, IT.

[21] Eastman Inc., Therminol 66 heat transfer fluid data sheet. April $2019 . \quad$ Available: https://www.therminol.com/sites/therminol/files/docum ents/TF-08_Therminol_66.pdf

[22] Ir. Ian C. Kemp, (2012). Fundamentals of eneregy analysis of dryers. Modern Drying Technology Volume 4: Energy Savings, First Edition. https://doi.org/10.1002/9783527631681.ch1

[23] Moran, M.J., Shapiro, H.N., Munson, B.R., Dewitt, D.P. (2011). Elementi di Fisica tecnica per l' ingegneria. Mc Graw Hill, 2011.

[24] Zhang, J.L., Qu, L.J., Wang, Z.Y., Zhao, Z.J., He, Z.B., Yi, S.L. (2017). Simulation and validation of heat transfer during wood heat treatment process. Results in Physics, 7: 3806-3812 https://doi.org/10.1016/j.rinp.2017.09.046

[25] Fock, F., Thomsen, K.P.B., Houbak, N., Henriksen, U.B. (2000). Modelling a biomass gasification system by means of EES. In Proceedings of SIMS Conference. Lyngby, pp. 179-186.
[26] Pedrazzi, S., Allesina, G., Puglia, M., Guidetti, L., Tartarini, P. (2015). Increased maize power production through an integrated biomas-gasification-SOFC power system. The Proceedings of the International Conference on Power Engineering (ICOPE). https://doi.org/10.1299/jsmeicope.2015.12._ICOPE-15$-2$

[27] Allesina, G., Pedrazzi, S., La Cava, E., Orlandi, M., Hanuskova, M., Fontanesi, C., Tartarini, P. (2014). Energy-based assessment of optimal operating parameters for coupled biochar and syngas production in stratified downdraft gasifiers. Proceedings of the 15th International Heat Transfer Conference, IHTC 2014. https://doi.org/10.1615/IHTC15.ees.008280

[28] Rehman, S., Bader, M.A., Al-Moallem, S.A. (2007). Cost of solar energy generated using PV panels. Renewable and Sustainable Energy Reviews, 11(8): 1843-1857. https://doi.org/10.1016/j.rser.2006.03.005

[29] EUROSTAT, July 2019, Available: http://appsso.eurostat.ec.europa.eu/nui/submitViewTabl eAction.do

[30] Atrill, P., McLaney, E. (2013). Accounting and Finance for Non-specialists Custon. eighth edition, Pearson.

[31] Allesina, G., Ferrari, C., Muscio, A., Pedrazzi, S. (2019). Easy to implement ventilated sunspace for energy retrofit of condominium buildings with balconies. Renewable Energy, 141: 541-548. https://doi.org/10.1016/j.renene.2019.04.037

[32] UNI 10349-1:2016, Riscaldamento e raffrescamento degli edifici - Dati climatici - Parte 1: Medie mensili per la valutazione della prestazione termo-energetica dell'edificio e metodi per ripartire l'irradianza solare nella frazione diretta e diffusa e per calcolare l'irradianza solare su di una superficie inclinata, 2016.

[33] Zhou, J.H., Cheung, C.S., Leung, C.W. (2014). Combustion, performance and emissions of a diesel with $\mathrm{H}_{2}, \mathrm{CH}_{4}$ and $\mathrm{H}_{2}-\mathrm{CH}_{4}$ addition. International Journal of Hydrogen Energy, 39(9): 4611-4621. https://doi.org/10.1016/j.ijhydene.2013.12.19

[34] Puglia, M., Pedrazzi, S., Allesina, G., Morselli, N., Tartarini, P. (2017). Vine prunings biomass as fuel in wood stoves for thermal power production. International Journal of Heat and Technology, 35(Sp1): S96-S101. https://doi.org/10.18280/ijht.35Sp0113

\section{NOMENCLATURE}

$\begin{array}{ll}\dot{M} & \text { Mass flow rate, } \mathrm{kg} \mathrm{s}^{-1} \\ c_{p} & \text { specific heat, } \mathrm{J}_{\mathrm{kg}} \mathrm{k}^{\circ} \mathrm{C}^{-1} \\ \dot{Q} & \text { power, } \mathrm{kW} \\ \mathrm{X} & \text { dimensionless moisture ratio } \\ \Delta \text { Hvap } & \text { water vaporization heat, } \mathrm{kJ} . \mathrm{kg}^{-1}{ }^{\circ} \mathrm{C}^{-1} \\ \mathrm{~T} & \text { Temperature },{ }^{\circ} \mathrm{C}\end{array}$

